\title{
Diversity Assessment of Lotic Macroalgal Flora by the Application of Taxonomic Distinctness Index
}

\author{
Aurélio Fajar Tonetto ${ }^{1,2}$, Pitágoras Conceição Bispo ${ }^{1}$ \& Ciro Cesar Zanini Branco ${ }^{I}$ \\ ${ }^{1}$ Universidade Estadual Paulista, Departamento de Biologia, Biologia Assis, São Paulo, SP, Brazil. \\ ${ }^{2}$ Corresponding author: Aurélio Fajar Tonetto, e-mail: tonettoaf@gmail.com
}

TONETTO, A.F., BISPO, P.C., BRANCO, C.C.Z. Diversity Assessment of Lotic Macroalgal Flora by the Application of Taxonomic Distinctness Index. Biota Neotropica. 16(1): e0085. http://dx.doi.org/10.1590/16760611-BN-2015-0085

\begin{abstract}
The main aim of this study was to assess the diversity of four stream algal divisions (Cyanobacteria, Chlorophyta, Ochrophyta and Rhodophyta) by comparing results obtained with taxonomic distinctness index and diversity patterns of previous studies. The data were obtained from a study made in 1000 stream segments in North American biomes. The taxonomic arrangement of the taxa was created from species to division level in order to obtain the taxonomic tree, which is used in taxonomic distinctness index. The results of taxonomic distinctness index showed that stream macroalgal diversity was different from that commonly found. Herein, Ochrophyta was the division with the highest diversity, whereas in previous studies Chlorophyta has been in the first position. Cyanobacteria also presented different results, showing the lowest diversity with taxonomic distinctness index, but it is often one of the most diverse divisions in previous studies. The application of statistical methods should match the research aims and be appropriate to the data set collected. However, different methods can complement ecological analyzes, taking into account what aspect of the community the statistical measure better explains.
\end{abstract}

Keywords: Biodiversity, taxonomic distinctness, macroalgae.

TONETTO, A.F., BISPO, P.C., BRANCO, C.C.Z. Avaliação da Biodiversidade de Macroalgas Lóticas pela Aplicação do Índice de Distintividade Taxonômica. Biota Neotropica. 16(1): e0085. http://dx.doi.org/ 10.1590/1676-0611-BN-2015-0085

Resumo: O objetivo deste estudo foi avaliar a diversidade de quatro divisões de algas de riachos (Cyanobacteria, Chlorophyta, Ochrophyta e Rhodophyta), comparando os resultados obtidos com o índice de distintividade taxonômica com os padrões de diversidade encontrados em trabalhos anteriores. Os dados foram coletados a partir de um estudo feito em 1000 segmentos de riachos em biomas da América do Norte. O arranjo taxonômico dos táxons foi criado a partir do nível de espécies até o nível de divisão, a fím de se obter a árvore taxonômica, que é utilizada no índice de distintividade taxonômica. Os resultados do índice de distintividade taxonômica mostraram que a diversidade de macroalgas de riachos foi diferente do que é comumente encontrado. Aqui, Ochrophyta foi a divisão com a maior diversidade, enquanto que no estudo original foi a divisão Chlorophyta. Cianobactérias também revelaram resultados diferentes, mostrando a menor diversidade com o índice de distintividade taxonômica, enquanto é frequentemente uma das mais diversas em trabalhos anteriores. A aplicação de métodos estatísticos deve coincidir com os objetivos da pesquisa e ser apropriada para o conjunto de dados coletados. No entanto, diferentes métodos podem complementar análises ecológicas, levando em consideração o aspecto da comunidade que a medida estatística melhor explica.

Palavras-chave: Biodiversidade, distintividade taxonômica, macroalgas.

\section{Introduction}

In many parts of the world, the scientific community has been producing studies about community ecology of lotic environments (Allan 1995). Stream macroalgae have raised interest because of their important role in the primary production of such environments (Sheath \& Burkholder 1985, Entwisle 1990, Sheath \& Cole 1992, Hu \& Xie 2006). In previous studies, diversity measures have been used as an important tool for a better understanding of the ecology of such organisms.
An example of such approach is the biogeographical distribution of lotic macroalgae. In such studies, researchers relate the diversity of several algal groups to the environmental conditions where they are. Hence, these organisms are mapped in relation to the environmental conditions (Sheath \& Cole 1992, Necchi 1989).

However, the diversity measures used in most of these studies may bring different results depending on the method or sampling used (Warwick \& Clarke 1991). More recently, the taxonomic distinctiness index (TDI) has been used as a measurement of diversity for several communities (Clarke \& Warwick 1995, 2001). 
A positive characteristic of such index is its independence of the sampling effort, which facilitates the use and comparison of different data types (Clarke \& Warwick 1998). Moreover, another aspect emphasized by TDI (and not raised by preceding models) is assigning weight to the taxonomic organization in the statistical analysis, which provides more detailed information about the diversity of communities.

So far, the application of this index has been limited to the assessment of fish biodiversity (Hall \& Greenstreet 1998), coral reefs and macrozoobenthos (Piepenburg et al. 1997, Mistri et al. 2000). Therefore, this statistical tool has been little used for algal flora. For instance, Ceschia et al. (2007) is the only study of this nature regarding seaweeds from marine environments. This study has assessed and compared the biodiversity of macroalgae in the Gulf of Trieste at two different times. The main aim of the authors was to assess the possible alterations in community structure owing to changes in environment, particularly those caused by human activities. The results of this study suggest that the level of TDI may have more general validity and, therefore, deserves to be further investigated.

Thus, we aimed to assess the diversity of lotic macroalgal communities in a wide region, applying the TDI, what was never used to assess the diversity of these organisms. Hence, we used data obtained from the taxonomic survey from 1,000 U.S. streams (Sheath \& Cole 1992) for the major biomes of North America. We expected that the application of TDI would reveal a different relationship between macroalgal diversity and the North America biomes.

\section{Materials and methods}

Investigations on diversity of lotic macroalgae using the TDI, and the reliability of the results of this study, were carried out based on data published in the study by Sheath \& Cole (1992). In this study, macroalgae were collected in 1,000 streams of North America, from latitude $73^{\circ} \mathrm{N}$ to $10^{\circ} \mathrm{N}$. The taxonomic survey of this study showed the presence of 259 species of macroalgae, grouped into four divisions (Cyanobacteria, Chlorophyta, Rhodophyta and Ochrophyta) and according to their occurrence in each biome. The list of species recorded by Sheath \& Cole (1992) was implemented in Microsoft ${ }^{\circledR}$ Office Excel program, in the form of two tables, namely: i) a table of presence/absence of species in each biome (Tundra, Boreal Forest, Conifers Forest, Hardwood-Hemlock Forest, Desert Chaparral, Deciduous Forest, Tropical Rainforest and Coastal Plain), and ii) a table with the systematic arrangement of the species up to division level. The systematic arrangement used to make this table was based on Wehr \& Sheath (2003). For the green algae (Chlorophyta), the taxonomic level family was taken away from analysis, since, according to Wehr \& Sheath (2003), this taxonomic level is not clearly defined.

The evaluation of diversity of each algal division (Cyanobacteria, Chlorophyta, Rhodophyta and Ochrophyta) by biome was carried out through the indices of taxonomic distinctness $\left(\Delta^{+}\right)$and variation in taxonomic distinctness $\left(\Lambda^{+}\right)$ based on qualitative data, as proposed by Warwick \& Clarke (1995) and Clarke \& Warwick (2001). The assessment of distinctness was performed using equal weights among hierarchical taxonomic levels (W: 111111). The values of $\Delta^{+}$ and $\Lambda^{+}$were graphed in accordance with the biomes. This procedure allowed the comparison of the diversity of each algal division in the habitats studied and also the verification of a possible correlation between $\Delta^{+}$and $\Lambda^{+}$.

Expected distinctness tests were applied in order to compare the results obtained from the TDI for each algal division and biome with expected values (Warwick \& Clarke 1998, Clarke \& Warwick 1998, 2001). This index is divided in two analyzes: Average Taxonomic Distinctness (AvTD or $\Delta^{+}$) and Variation in Taxonomic Distinctness (VarTD or $\Lambda^{+}$). The value of $\Delta^{+}$is simply calculated by adding the paths that connect each pair of species in a taxonomic tree divided by the number of paths (Warwick \& Clarke 1995). Such paths are assumed to be the steps between each hierarchical level: species to genus, the genus to family, up to the same level of the species pair (Figure 1).

However, Clarke \& Warwick (2001) realized that it would be feasible to observe equal values of $\Delta^{+}$to communities that possess a distinct taxonomic structure, although with the same number of species. The example in Figure 2 suggests that a community with species belonging to several genera and one family may have $\Delta^{+}$equal to another community with the same number of species, but belonging to a few genera and more families. Such differences in taxonomic structures can be observed by the variability of the distances between pairs in relation to the mean value, which is calculated by $\Delta^{+}$. The change in the taxonomic distinctness $\left(\Lambda^{+}\right)$is simply the variance of the path traveled between the pairs of a taxonomic tree species.

The taxonomic distinctness observed $\left(\Delta^{+}\right.$and $\left.\Lambda^{+}\right)$was compared with a reliance interval of $95 \%$, based on random testing (5,000 randomizations) of the list of species of each algal division. The representation of results from this test can be represented by a funnel-shaped or ellipse chart. Such graphs describe a reliance interval $(95 \%)$ calculated from the mean values of the index for each subgroup size within the total pool of species of each algal division. In this sense, the actual values of $\Delta^{+}$and $\Lambda^{+}$in the funnel/ellipse will be in the expected diversity limits for that species pool and, as a consequence, the values being positioned below or above the limits of the funnel/ellipse

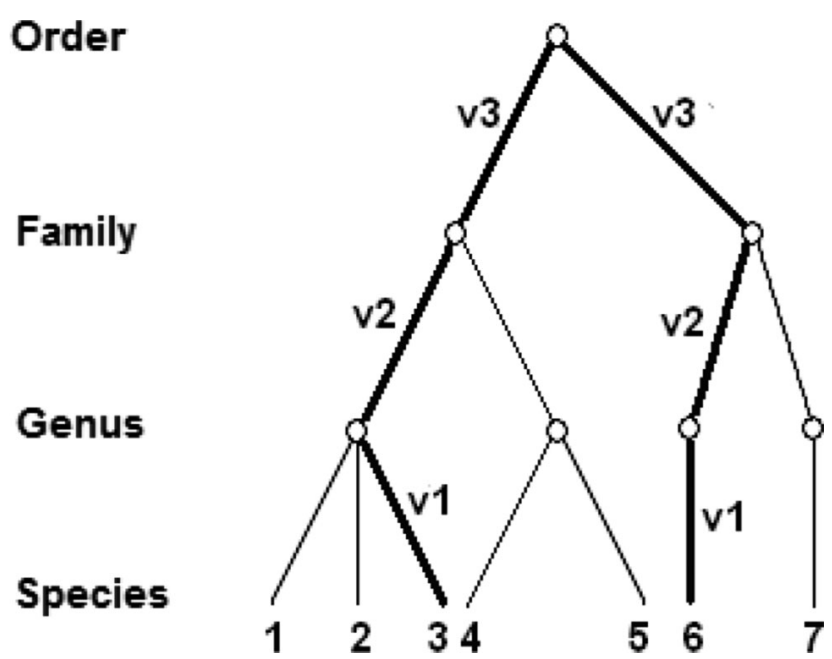

Figure 1. Example of Taxonomic tree with a sample of 7 species showing the definition for steps (p1 - p6) traveled through hierarchical levels between a pair of species (in this case 3 and 6). A simple average for these paths defines the index of taxonomic distinctness $\left(\Delta^{+}\right.$or AvTD). Figure extracted from Clarck \& Warwick (1998). 

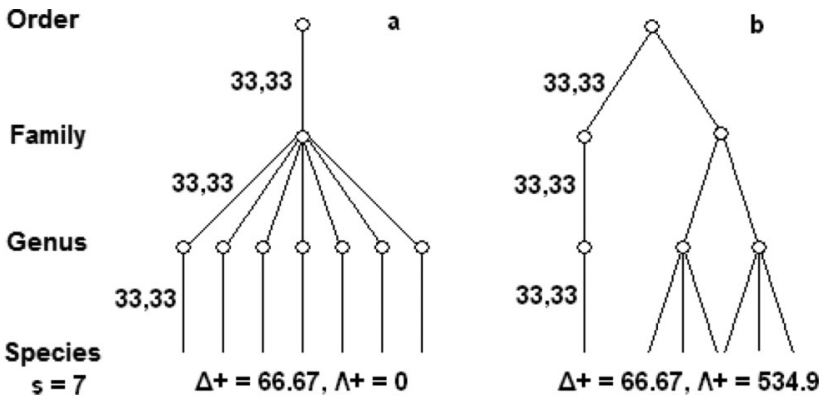

Figure 2. Two examples of taxonomic trees ( $a$ and b) in which the index of taxonomic distinctness $\left(\Delta^{+}\right)$is identical, but the variation in taxonomic distinctness $\left(\Lambda^{+}\right)$differs substantially, reflecting a large gap between the structure of trees. Figure extracted from Clarck \& Warwick (1998).

will be understood to have respectively higher and lower than expected range.

All analyses were carried out using PRIMER 5.0 for Windows.

\section{Results}

The results showing the numbers of species and the values of $\Delta^{+}$and $\Lambda^{+}$for algal division by biome/region are shown in Tables 1-2 and Figures 3-4.

Cyanobacteria exhibited the highest value of $\Delta^{+}$(AvTD) in the Tundra biome and the lowest value for Coastal Plain (Table 1, Figure 3). The comparison between observed $\Delta^{+}$and the expected limits based on randomization of subsets from the overall species pool (Figure 4) showed that only Coastal Plain biome recorded values outside the reliance interval of $95 \%$. Furthermore, it was clear that although only the Coastal Plain biome was below the lower limit of the funnel, the index values for the Deciduous Forest, Coniferous Forest and Hemlock-Hardwood Forest were positioned below the global mean of division, while the biomes of Tropical Rainforest and Boreal Forest recorded values near the global average.

Considering the division Rhodophyta, the TDI values showed that Desert Chaparral has the highest diversity for this algal group, whereas Tundra showed the lowest (Table 1, Figure 3). The analysis of the funnel for this algal division showed that, while no biome was outside the limits of the reliance interval, the index values were below the overall

Table 1. Values of $\Delta^{+}$and the number of species sampled for each algal division by biome. TU - Tundra, BF - Boreal Forest, CF Conifers Forest, HH - Hemlock-Hardwood Forest, DF - Deciduous Forest, CP - Coastal Plain, TR - Tropical Rainforest and DC - DesertChaparral.

\begin{tabular}{lclll}
\hline & Cyanobacteria & Chlorophyta & Rhodophyta & Ochrophyta \\
\hline TU & $59,16(16)$ & $69,66(26)$ & $50,66(6)$ & $82,22(6)$ \\
BF & $56,66(20)$ & $64,89(40)$ & $56,36(11)$ & $80,07(28)$ \\
CF & $54,94(14)$ & $67,37(34)$ & $52,16(16)$ & $80,17(20)$ \\
HH & $55,07(21)$ & $69,93(30)$ & $56,04(14)$ & $79,92(19)$ \\
DF & $52,38(7)$ & $67,47(39)$ & $53,52(15)$ & $79,33(19)$ \\
CP & $45,45(12)$ & $71,20(38)$ & $54,61(19)$ & $81,83(13)$ \\
TR & $56,71(26)$ & $72,86(26)$ & $67,09(22)$ & $85,11(8)$ \\
DC & $57,77(6)$ & $71,89(18)$ & $68,33(9)$ & $82,53(7)$ \\
\hline
\end{tabular}

Table 2. Values of $\Lambda^{+}$for each algal division by biome. TU - Tundra, BF - Boreal Forest, CF - Conifers Forest, HH - Hemlock-Hardwood Forest, DF - Deciduous Forest, CP - Coastal Plain, TR - Tropical Rainforest and DC - Desert-Chaparral.

\begin{tabular}{lcccc}
\hline & Cyanobacteria & Chlorophyta & Rhodophyta & Ochrophyta \\
\hline TU & 179,86 & 282,03 & 686,22 & 795,06 \\
BF & 221,63 & 321,14 & 524,95 & 631,62 \\
CF & 259,42 & 297,05 & 628,63 & 650,84 \\
HH & 254,62 & 285,74 & 590,94 & 626,76 \\
DF & 325,01 & 312,79 & 613,29 & 771,88 \\
CP & 215,02 & 265,82 & 771,05 & 820,41 \\
TR & 203,58 & 200,11 & 576,43 & 344,03 \\
DC & 291,35 & 221,89 & 583,88 & 594,60 \\
\hline
\end{tabular}

average, except for Tropical Rainforest and Desert Chaparral (Figure 4).

Values of $\Delta^{+}$for Chlorophyta division showed that maximum diversity of green algae was found in the Tropical Rainforest biome and the lowest one was observed in the Boreal Forest biome (Table 1, Figure 3). Index values were relatively heterogeneous among biomes, which led to an obvious scattering of biomes within and outside the limits of the reliance interval (Figure 4). The biomes of Conifers Forest, Deciduous Forest and Boreal Forest were positioned below the expected limit for the division. Other biomes lie within the funnel, some positioned above the global average and others close to it.

Finally, for Ochrophyta division, the TDI values for all biomes were high. The Tropical Rainforest biome was the one which recorded the highest $\Delta^{+}$, whereas the Deciduous Forest biome the lowest (Table 1, Figure 3). The high values of $\Delta^{+}$ showed for this division were reflected in the positioning of all biomes above the global average of species, although included within the limits of reliance interval (Figure 4).

The TDI values for lotic macroalgae communities from the studied biomes in North America showed that the Tropical Rainforest recorded the greatest diversities for two algal divisions (Chlorophyta and Ochrophyta) and also high values for the two other divisions (Table 1). On the other hand, Coastal Plain reported the lowest value of TDI (Cyanobacteria).

Table 3 shows the comparison between algal division diversity found here (using TDI) and the diversity found in previous studies. It is clear that Ochrophyta and Cyanobacteria changed their position among algal group diversity. While TDI revealed that Ochrophyta exhibited the highest diversity, in previous studies it was typically found as one of the lowest diverse group. Similarly, Cyanobacteria exhibited the lowest diversity regarding TDI analyses, but previously it was the opposite.

\section{Discussion}

The results of diversity from TDI found in this study will be discussed considering the main general patterns of stream macroalgal diversity reported in previous studies, including Sheath \& Cole (1992) (e.g., Sheath \& Burkholder 1985, Branco et al. 2009, Peres et al. 2010).

In general, Chlorophyta is reported as the most diverse division of algae in lotic macroalgae communities around the world (Sheath \& Burkholder 1985, Sheath \& Cole 1992, 
Cyanobacteria

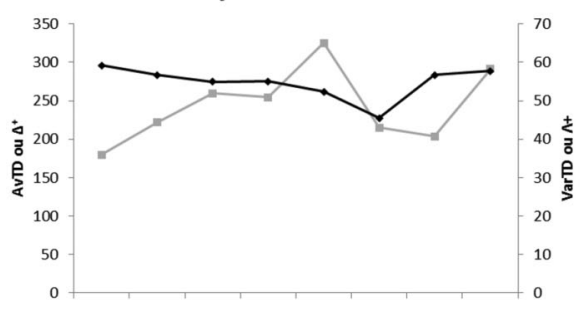

Rhodophyta

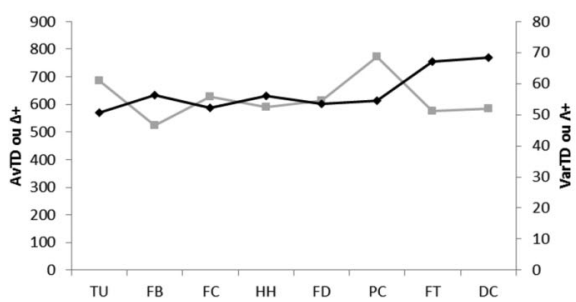

Chlorophyta

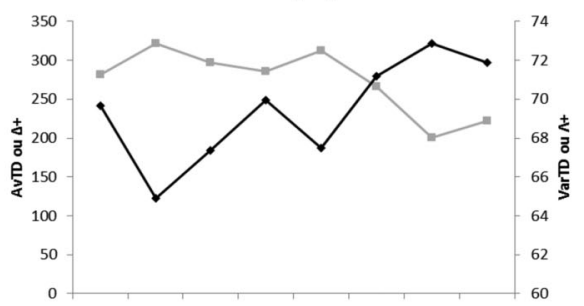

Ochrophyta

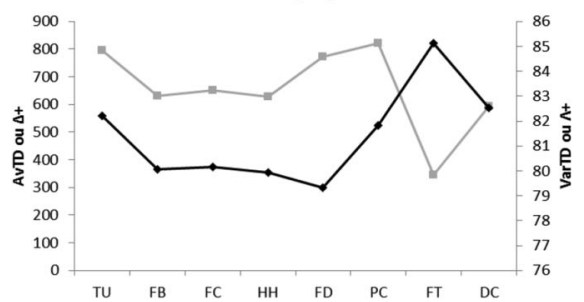

Figure 3. Values of $\Delta^{+}(\downarrow)$ and $\Lambda^{+}(\boldsymbol{\square})$ for algal divisions according to the biomes. TU - tundra, BF - Boreal Forest, CF - Conifers Forest, HH - Hemlock-Hardwood Forest, DF - Deciduous Forest, CP - Coastal Plain, TR - Tropical Rainforest, and DC - Desert-Chaparral.

Branco et al. 2009, Peres et al. 2010). The same tendency was observed in Sheath \& Cole (1992). However, using the TDI, the most diverse algal division was the brown algae. According to several studies involving classic measures of macroalgal diversity, Ochrophyta consistently appears as a group with low values of diversity (e.g. Krupek \& Branco 2012, Necchi et al. 2003). In this context, our findings suggest that there is a high dispersion of their species along the taxonomic gradient, despite the brown macroalgae of lotic systems, which showed a limited occurrence and distribution.

Similar to Chlorophyta, Cyanobacteria has been considered as one of the most diverse algal group showing recurrently high specific richness (Krupek et al. 2007, Necchi et al. 2003). However, the diversity of Cyanobacteria of North American streams, when applied the TDI, was the lowest among the four algal divisions analyzed. Although commonly exhibiting high occurrence, the species of this taxonomic group show low taxonomic dispersion, which means that the species found in the study area belong to few taxonomic groups.

Using TDI to investigate the latitudinal distribution of stream macroalgal groups, we observed that the green algae showed a clear latitudinal tendency, with values of diversity increasing from the Arctic to the tropics. This biogeographycal trend shown by $\Delta^{+}$could not be recognized from the species richness data alone, and it is in complete accordance with increment in irradiance toward the tropics (Hut et al. 2013) and with the preference for a larger quantity of light typically observed for Chlorophyta (Richardson et al. 1983, Necchi Jr. 2004). Furthermore, pigment
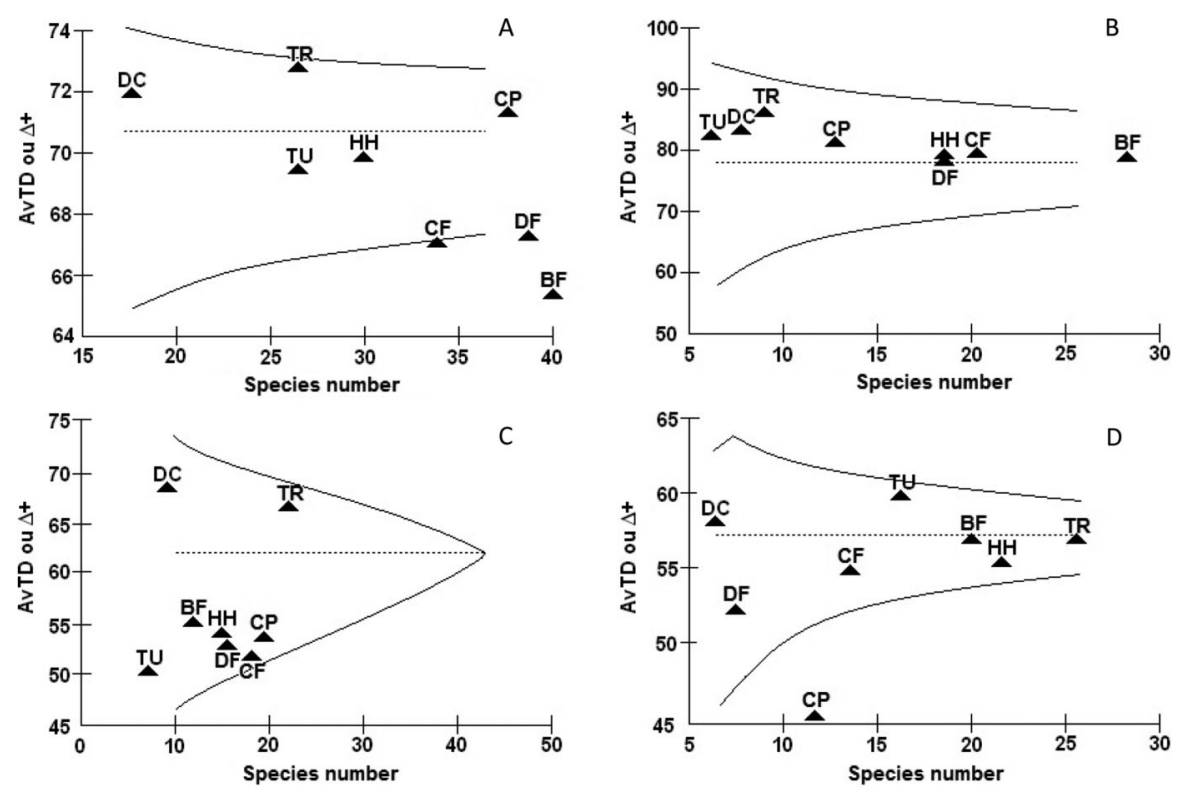

Figure 4. Graphical representation of the values of average taxonomic distinctness $\left(\Delta^{+}\right)$observed in each algal division by biome investigated. These values are compared with expected diversity values represented by the funnel. A - Chlorophyta; B - Ochrophyta; C - Rhodophyta; D - Cyanobacteria. 
Table 3. Hierarchical diversity of algal divisions (Cyanobacteria, Chlorophyta, Rhodophyta and Ochrophyta) in the present study (using Taxonomic Distinctness Index) and previous studies (richness).

\begin{tabular}{|c|c|c|c|c|}
\hline \multirow[t]{2}{*}{ Literature } & \multicolumn{4}{|c|}{ Algal Divisions } \\
\hline & Higher divesity & & $\longrightarrow$ & Lower diversity \\
\hline \multicolumn{5}{|l|}{ Present study } \\
\hline Taxonomic Distinctness Index (TDI) & Ochrophyta & Chlorophyta & Rhodophyta & Cyanobacteria \\
\hline \multicolumn{5}{|l|}{ Previous sudies } \\
\hline Sheath \& Cole 1992, North America & Chlorophyta & Cyanobacteria & Ochrophyta & Rhodophyta \\
\hline Necchi et al. 1995, Southeastern Brazil & Chlorophyta & Cyanobacteria & Rhodophyta & Ochrophyta \\
\hline Branco et al. 2008, South Brazil & Chlorophyta & Cyanobacteria & Ochrophyta & Rhodophyta \\
\hline Sherwood 2006, Hawaiian Islands & Chlorophyta & Cyanobacteria & Ochrophyta & Rhodophyta \\
\hline Hu \& Xie 2006, North China & Chlorophyta & Cyanobacteria & Ochrophyta & Rhodophyta \\
\hline Bojorge-Garcia et al. 2010, Central Mexico & Chlorophyta & Rhodophyta & Cyanobacteria & Ochrophyta \\
\hline
\end{tabular}

contents of the green algae exhibit more efficient physiological activity under high irradiance (DeNicola \& Hoagland 1992).

Considering the values of the TDI, we found that the most diverse biome was the Tropical Rainforest, with the highest values for Chlorophyta and Ochrophyta, and very high values for Rhodophyta and Cyanobacteria. This is a relevant result, mainly when confronted with data from species richness, a very common type of information used to describe and discuss stream macroalgal community structure and biogeography (see, for instance, the discussion presented by Sheath \& Cole 1992). If only the species richness is considered, Boreal Forest was the North American biome with highest diversity in stream macroalgal communities. It is known that the characteristics of biomes are relevant in determining patterns of diversity and distribution of macroalgae communities (McGregor et al. 2006, Oliveira et al. 2013), but depending on the information used in these analyzes we can end up in different conclusions, even contradictory, as shown in the comparison presented above.

Regarding all results and discussion made herein, we showed that using TDI, algal groups contribute differently on stream macroalgal diversity than showed by previous studies. However, TDI cannot substitute other diversity measurements such as number of species or Shannon diversity (Ceschia et al. 2007). Instead of this, it is important to combine the statistical analyses to the project goals. Warwick \& Clarke (2001) made a comparison among statistical analyses, and they found that some methods are more sensitive than others. Thus, in general, the data must be analyzed properly and in consonance to researcher's questions, what may help to improve the interpretation of the information.

More specifically, traditional diversity measures based on species richness and evenness exhibit disadvantages regarding the assessment of biodiversity change on wide spatial and temporal scales (Warwick \& Clarke 2001). Hence, measures based on species relatedness (e.g. taxonomic distinctness) rose to overcome these problems and they have been used widely for conservation purposes. Herein, we showed the differences between TDI results and typical lotic macroalgal diversity found previously. So, we suggest that TDI should be used as a complementary measure to species richness, which would favors a more accurate definition of biodiversity conservation priorities (Loidi et al. 2015). For instance, a species without close relations to any others would have higher priority for conservation than a species with many close relatives (Warwick \& Clarke 2001).
In this context, it is possible to observe that the application of different diversity measures may reveal different results and conclusions, even based on the same data set. Although species richness have been used to assess the diversity in conservation programs, the taxonomic indices as TDI would help to understand better the general diversity patterns and to improve strategies of biodiversity conservation (Loidi et al. 2015), not only for stream macroalgae. Furthermore, TDI could be used in broad scale geographical comparisons of biodiversity, regarding more ecological questions, mainly those related to contrasting habitats. Finally, we expect that TDI must be further investigated to find application in a broad sense.

\section{Acknowledgements}

The authors would like to thanks to FAPESP for financial support granted to AFT (Proc. 2010/17563-0) and to CCZB (Proc. 2014/22952-6); and to $\mathrm{CNPq}$ for financial support granted to CCZB (Proc. 302354/2008-5).

\section{References}

ALLAN, D.J. 1995. Stream Ecology: structures and functions of running waters. Universidade de Michigan, EUA. Kluwer Academic Publishers.

BRANCO, C.C.Z., KRUPEK, R.A. \& PERES, C.K. 2009. Distribution of stream macroalgal communities from the mid-western region of Paraná State, southern Brazil: Importance of local scale variation. Braz. Arch. Biol. Technol. 52:379-386, http://dx.doi.org/ 10.1590/S1516-89132009000200015.

CESCHIA, C., FALACE, A. \& WARWICK, R.M. 2007. Biodiversity evaluation of the macroalgal flora of the Gulf of Trieste (Northern Adriatic Sea) using taxonomic distinctness indices. Hydrobiology 580:43-56, http://dx.doi.org/10.1007/s10750-006-0466-8.

CLARKE, K.R. \& WARWICK, R.M. 1998. A taxonomic distinctiness index and its statiscal properties. J. Appl. Ecol. 35:523-531.

CLARKE, K.R. \& WARWICK, R.M. 2001. A further biodiversity index applicable to species list: variation in taxonomic distinctness. Mar. Ecol. Progr. Ser. 216:265-278, http://dx.doi.org/10.3354/ meps 216265 .

DENICOLA, D.M. \& HOAGLAND, K.D. 1992. Influences of canopy cover on spectral irradiance and periphyton assemblages in a prairie stream. J. North. Am. Benthol. Soc., 11:391-404, http://dx.doi.org/ $10.2307 / 1467560$

ENTWISLE, T.J. \& ANDERSEN, R.A. 1990. A re-examination of Tetrasporopsis (Chrysophyceae) and the description of Dermatochysis gen. 
nov. (Chrysophyceae): a monostromatic alga lacking cell walls. Phycologia 29:263-274, http://dx.doi.org/10.2216/i0031-8884-29-3-263.1.

HALL, S.J. \& GREENSTREET, S.P. 1998. Taxonomic distinctness and diversity measures: responses in marine fish communities. Mar. Ecol. Progr. Ser. 166:227-229.

HU, B.F. \& XIE, S.L. 2006. Effect of seasonality on distribution of macroalgae in a stream system (Xinan Spring) in Shanxi Province, North China. Journal of Integrative Plant Biol. 48(8):889-896, http://dx.doi.org/10.1111/j.1744-7909.2006.00317.x.

KRUPEK, R.A., BRANCO, C.C.Z. \& PERES, C.K. 2007. Distribuição ecológica das comunidades de macroalgas da bacia de drenagem do Rio das Pedras, região Centro-Sul do Estado do Paraná, Sul do Brasil. Rev. Bras. Bot. 30(2):173-182.

KRUPEK, R.A. \& BRANCO, C.C.Z. 2012. Ecological distribution of stream macroalgae in different spatial scales using taxonomic and morphological groups. Braz. J. Bot. 35(3): 273-280.

LOIDI, J., CAMPOS, J.A., HERRERA, M., BIURRUN, I., GARCÍA-MIJANGOS, I. \& GARCÍA-BAQUERO, G. 2015. Ecogeographical factors affecting richness and phylogenetic diversity patterns of high-mountain flora in the Iberian Peninsula. Alpine Botany. 125(2):137-146, http://dx.doi.org/10.1007/s00035-015-0149-z.

MISTRI, M., CECCHERELLI, V.U. \& ROSSI, R. 2000. Taxonomic distinctness and diversity measures: responses in lagoonal macrobenthic communities. Ital. J. Zool. 67:297-301, http://dx.doi.org/ 10.1080/11250000009356327.

NECCHI, O.Jr. 1989. Geographical distribution of the genus Batrachospermum (Rhodophyta, Batrachospermales) in Brazil. Ver. Bras. Biol. 49:663-669.

NECCHI, O.Jr., BRANCO, L.H.Z. \& BRANCO, C.C.Z. 2003. Ecological distribution of stream macroalgal communities from a drainage basin in the Serra da Canastra National Park, Minas Gerais, Southeastern Brazil. Braz. J. Biol. 63:1-12, http://dx.doi.org/10.1127/ 1863-9135/2010/0178-0017.

NECCHI, O.Jr. 2004. Light-related photosynthetic characteristics of lotic macroalgae. Hydrobiologia, 525:139-55, http://dx.doi.org/ 10.1023/B:HYDR.0000038861.18999.7b.
PERES, C.K., BRANCO, C.C.Z. \& KRUPEK, R.A. 2010. Longitudinal distribution and seasonality of macroalgae in a subtropical stream impacted by organic pollution. Acta Limnol. Bras. 22 (2):199-207, http://dx.doi.org/10.4322/actalb.02202009.

PIEPENBURG, D., VOSS, J. \& GUTT, J. 1997. Assemblages of sea stars (Echinodermata: Asteroidea) and brittle stars (Echinodermata: Ophiuroidea) in the Weddel Sea (Antarctica) and off Northeast Greend (Arctic): a comparison of diversity and abundance. Pol. Biol. 17:305-322, http://dx.doi.org/10.1007/PL00013372.

RICHARDSON, K., BEARDALL, J. \& RAVEN, J.A., 1983. Adaptation of unicellular algae to irradiance: An analysis of strategies. New Phytol. 93:157-91, http://dx.doi.org/10.1111/j.1469-8137.1983. tb03422.x.

WHER, J.D. \& SHEATH, R.G. 2003. Freshwater Algae of North America - Ecology and Classification. Aquatic Ecology Series.

HUT, R.A., PAOLUCCI, S., DOR, R., KYRIACOU, C.P. \& DAAN, S. 2013. Latitudinal clines: an evolutionary view on biological rhythms. Proceedings of the Royal Society, http://dx.doi.org/ 10.1098/rspb.2013.0433.

SHEATH, R.G. \& BURKHOLDER, J.M. 1985. Characteristics of softwater streams in Rhode Island. II: Composition and seasonal dynamics of macroalgal communities. Hydrobiologia 128:109-118, http://dx.doi.org/10.1007/BF00008730.

SHEATH, R.G. \& COLE, K.M. 1992. Biogeography of stream macroalgae in North America. J. Phycol. 28:448-460, http://dx.doi.org/ 10.1111/j.0022-3646.1992.00448.x.

WARWICK, R.M. \& CLARKE, K.R. 1991. A Comparison of some methods for analysing changes in benthic community structure. J. Mar. Biol. Ass. U. K. 71:225-244, http://dx.doi.org/10.1017/S0025 315400037528.

WARWICK, R.M. \& CLARKE, K.R. 1995. New "biodiversity" measures reveal a decrease in taxonomic distinctness with increasing stress. Mar. Ecol. Progr. Ser. 129:301-305.

WARWICK, R.M. \& CLARKE, K.R. 1998. Taxonomic distinctness and environment assessment. J. App. Ecol. 35:532-543, http://dx.doi.org/ 10.1046/j.1365-2664.1998.3540532.x. 